\title{
ST
}

Science \& Technology

PAPER - OPEN ACCESS

\section{Penerapan Strategi Pembelajaran TGT Dibandingkan dengan TSTS Dalam Meningkatkan Hasil Belajar Kimia Siswa}

\author{
Author : Doli Harahap dkk., \\ DOI $\quad: 10.32734 /$ st.v2i1.335 \\ Electronic ISSN $\quad: 2654-7082$ \\ Print ISSN : :2654-7074
}

Volume 2 Issue 1 - 2018 TALENTA Conference Series: Science \& Technology (ST)

This work is licensed under a Creative Commons Attribution-NoDerivatives 4.0 International License.

Published under licence by TALENTA Publisher, Universitas Sumatera Utara

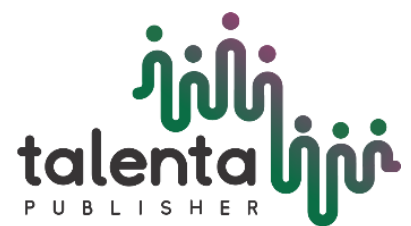




\title{
jibli talentaliois \\ TM Conference Series 02 (2019) \\ TALENTA Conference Series
}

Available online at https://talentaconfseries.usu.ac.id

\section{Penerapan Strategi Pembelajaran TGT Dibandingkan dengan TSTS Dalam Meningkatkan Hasil Belajar Kimia Siswa}

\author{
Doli Fadly Harahap ${ }^{a *}$, Suharta ${ }^{b}$, Predi S. Perangin Angin ${ }^{c}$ dan \\ Rian Rahmansyah ${ }^{\mathrm{d}}$.
}

${ }^{a}$ Program Studi Pendidikan Kimia, Pascasarjana, Universitas Negeri Medan, Medan

fadlydy23@gmail.com

\begin{abstract}
Abstrak
Penelitian ini bertujuan untuk mengetahui perbedaan peningkatan hasil belajar kimia siswa yang diajarkan dengan Strategi Pembelajaran Two Stay Two Straydibandingkan Teams Games Tournament dengan media Power Point, pada pokok bahasan Larutan Elektrolit dan Nonelektrolit. Populasi dalam penelitian ini adalah seluruh kelas X MAN 2 Model Medan, yang berjumlah11 kelas dan setiap kelas terdiri dari 36 siswa. Sampel dalam penelitian ini sebanyak 2 kelas yang diambil secara acak. Instrumen yang digunakan dalam penelitian ini adalah tes hasil belajar dalam bentuk pilihan berganda dengan jumlah soal sebanyak 22 soal yang telah dinyatakan valid dan reliabel serta lembar observasi tanggung jawab. Hasil penelitian menunjukkan bahwa Tidak terdapat perbedaan yang signifikan Hasil belajar siswa yang diajarkan dengan strategi pembelajaran TSTS dengan media Power Point dibandingkan siswa yang diajar dengan kooperatif tipe TGT dengan media Power Point (sig. 0,480 > 0,05).
\end{abstract}

Kata Kunci : TGT, TSTS, Strategi Pembelajaran.

\section{Pendahuluan}

Undang-Undang No. 20 tahun 2003 tentang sistem pendidikan nasional menyebutkan "Pendidikan nasional berfungsi mengembangkan kemampuan dan membentuk watak serta peradaban bangsa yang bermartabat dalam rangka mencerdaskan kehidupan bangsa, bertujuan untuk berkembangnya potensi peserta didik agar menjadi manusia yang beriman dan bertakwa kepada Tuhan Yang Maha Esa, berakhlak mulia, sehat, berilmu, cakap, kreatif, mandiri, dan menjadi warga negara yang demokratis serta bertanggung jawab". Oleh karena itu, sebagai pendidik tidak hanya bertugas untuk mencerdaskan saja tetapi juga harus mengembangkan karakter-karakter peserta didik seperti yang telah dikemukakan pada pasal tersebut [1].

Kimia merupakan mata pelajaran yang sulit. Materi Pelajaran Kimia di SMA banyak berisi konsep-konsep yang cukup sulit untuk difahami siswa, karena menyangkut reaksi-reaksi kimia dan hitungan-hitungan serta menyangkut konsep-konsep yang bersifat abstrak sehingga kurang menarik. Jadi, ketika guru memberikan tugas atau PR kepada siswa banyak siswa yang tidak mengerjakan dengan alasan siswa belum paham terhadap materi yang diberikan. Dengan begitu siswa tidak memiliki karakter terutama karakter tanggung jawab dalam diri siswa, karena siswa tidak menyelesaikan tugas atau PR yang diberikan kepadanya dan juga ini berpengaruh pada hasil belajar siswa yang dapat menurun. Disinilah guru memerlukan strategi dalam mengajar juga media atau alat bantu/alat peraga untuk mengatasi masalah diatas agar hasil belajar siswa tidak menurun bahkan bisa meningkat dan karakter dapat muncul pada diri siswa [2].

Pada penelitian ini, peneliti memakai dua strategi pembelajaran yaitu strategi pembelajaran kooperatif tipe Two Stay Two Stray (TSTS) dengan strategi pembelajaran Teams Games Tournament (TGT). Kedua strategi pembelajaran ini masing-masing memiliki beberapa kelebihan, begitu juga dengan media yang digunakan. Dalam hal ini strategi pembelajaran kooperatif tipe Two Stay Two Stray menitik beratkan pada kerja sama yaitu dengan 
adanya kelompok. Setiap anggota kelompok memiliki peran dan tugasnya masing-masing sehingga setiap anggota bertanggung jawab atas tugasnya masing-masing, karena nanti hasilnya akan menyangkut kelompoknya dan kelompok yang lain. Strategi kooperatif tipe Two Stay Two Stray memberikan kesempatan kepada kelompok untuk membagi tugas dan hasil juga informasi dengan kelompok lain. Sehingga diharapkan dapat mendorong tumbuhnya tanggung jawabsiswa dan peningkatan hasil belajar.

Pada Strategi pembelajaran Teams Games Tournament (TGT) adalah salah satu tipe atau strategi pembelajaran kooperatif yang mudah diterapkan, melibatkan aktivitas seluruh siswa tanpa harus ada perbedaan status, melibatkan peran siswa sebagai tutor sebaya dan mengandung unsur permainan dan reinforcement. Dimana pada saat permainan berlangsung, setiap anggota tim memiliki peran dan tugasnya masing-masing dan bertanggung jawab atas hasil yang diberikannya karena hasilnya tersebut memberikan dampak terhadap hasil kelompoknya. Aktivitas belajar dengan permainan yang dirancang dalam pembelajaran kooperatif strategi Teams Games Tournament (TGT) memungkinkan siswa dapat belajar lebih rileks disamping menumbuhkan tanggung jawab, kejujuran, kerja sama, persaingan sehat dan keterlibatan belajar.

Hasil penelitian Hasibuan [3], Efektivitas Pembelajaran kooperatif tipe Two Stay Two Stray yang diintegrasi dengan media Molymod pada pokok bahasan hidrokarbon adalah sebesar 20,45 \%. Hasil penelitian Rizki [4], Efektivitas Pembelajaran kooperatif tipe Two Stay Two Stray pada pokok bahasan sistem pencernaan dapat meningkatkan prestasi belajar siswa sebesar 32.14\%.

Hasil penelitian Utari [5], menyatakan penggunaan pembelajaran kooperatif tipe TGT menunjukkan peningkatan sebesar 69,5\%, dan hasil penelitian Marpaung [6] juga menunjukkan peningkatan sebesar 27,7\%. Adapun Lubis [7] menyatakan strategi pembelajaran kooperatif tipe TGT memiliki peningkatan hasil belajar sebesar $60,8 \%$.

Berdasarkan latar belakang dan pemikiran tersebut, maka penulis tertarik untuk mengadakan penelitian yang berjudul "PENERAPAN STRATEGI PEMBELAJARAN TGT DIBANDINGKAN DENGAN TSTS DALAM MENINGKATKAN HASIL BELAJAR KIMIA SISWA”.

\section{Metode}

Pada penelitian ini digunakan dua metode pembelajaran kooperatif, yang pertama metode pembelajaran kooperatif TSTS (Teo Stay Two Stray) dan yang kedua metode pembelajaran kooperatif TGT (Teams Games Tournament).

\section{Strategi Pembelajaran Kooperatif Two Stay Two Stray (TSTS)}

Strategi pembelajaran TSTS ini dikategorikan sebagai strategi pembelajaran aktif dan kooperatif. strategi pembelajaran ini merupakan cara belajar aktif, menarik, penuh partisipasi dan tidak hanya untuk belajar tetapi juga untuk meningkatkan kemampuan pembelajaran.

Penelitian dengan menggunakan strategi ini menggunakan tiga tahapan yaitu: tahap persiapan, tahap penyampaian, dan tahap refleksi. Tahap persiapan bertujuan untuk mempersiapkan kesiapan materi dan mental peserta didik untuk belajar. Sebelum memulai persiapan materi, mental peserta yang pasif dari segala rintangan belajar dihilangkan terlebih dahulu. Persiapan sikap mental bisa dilakukan dengan memberikan motivasi atau aktifitas pendek yang penuh dengan humor yang ditunjukkan pada semua peserta. Aktivitas ini biasa disebut dengan ice breakers. Materi yang dibahas dalam satu kelompok adalah sama pada setiap peserta, baik peserta yang bertugas sebagai tamu atau peserta yang bertugas sebagai peserta.

Menurut Lie [8], ada beberapa langkah yang harus ditempuh dalam Strategi Pembelajaran Kooperatif tipe TSTS:

1. Guru membagi siswa menjadi beberapa kelompok, setiap kelompok terdiri dari 4-6 orang siswa masing-masing kelompok harus memilih satu orang siswa sebagai ketua kelompok.

2. Tiap kelompok diberi satu topik yang berbeda yang harus dibahas dalam diskusi. Tiap kelompok mendiskusikan topik yang telah ditentukan oleh guru. Tiap kelompok menyiapkan satu buku tamu untuk mencatat semua informasi dari kelompok lain.

3. Setelah batas waktu yang ditentukan diskusi dalam kelompok selesai. Masing-masing kelompok mengutus dua anggota untuk bertamu ke kelompok lain dan anggota kelompok lainnya menerima tamu secara bergantian menurut waktu yang ditentukan oleh guru. 
4. Setelah ada aba-aba dari guru, siswa yang bertugas sebagai tamu berdiri tapi tidak langsung kembali ke kelompok asalnya melainkan melanjutkan perjalanan bertamunya ke kelompok lain secara bersamaan sampai semua kelompok lain dikunjungi . Sedangkan anggota yang bertugas sebagai penerima tamu hanya tinggal di tempat menunggu kedatangan tamu dari kelompok lain.

5. Tamu kembali ke kelompoknya lalu menyempurnakan materi atau pertanyaan yang telah dicatat dalam buku tamu. Apabila ada masalah yang tidak bisa diselesaikan dicatat dalam buku tamu untuk didiskusikan secara keseluruhan bersama guru.

6. Tiap kelompok mengadakan presentasi di depan kelas secara bergantiana yang tinggal (menerima tamu).

\section{Strategi Pembelajaran Kooperatif Tipe Teams Games Tournament (TGT)}

Menurut David de Vries dab Keath Edward [9] strategi pembelajaran kooperatif tipe Team Games Tournament (TGT), atau pertandingan permainan tim dikembangkan secara asli oleh mereka. Pada strategi ini siswa memainkan permainan dengan anggota-anggota tim lain untuk memperoleh tambahan poin untuk skor tim mereka.

Dalam penerapan strategi pembelajaran kooperatif tipe TGT [10] ada beberapa tahapan yang perlu ditempuh yaitu :

\section{1) Mengajar (teach)}

Mempersentasekan atau menyajikan materi, menyampaikan tujuan, tugas, atau kegiatan yang harus dilakukan siswa, dan memberikan motivasi.

2) BelajarKelompok (teamstudy)

Siswa bekerja dalam kelompok yang terdiri atas 5 sampai 6 orang dengan kemampuan akademik, jenis kelamin, dan ras / suku yang berbeda. Setelah guru menginformasikan materi, dan tujuan pembelajaran, kelompok berdiskusi dengen menggunakan LKS. Dalam kelompok terjadi diskusi untuk memecahkan masalah bersama, saling memberikan jawaban dan mengoreksi jika ada anggota kelompok yang salah dalam menjawab.

3) Permainan (game tournament)

Permainan diikuti oleh anggota kelompok dari masing-masing kelompok yang berbeda. Tujuan dari permainan ini adalah untuk mengetahui apakah semua anggota kelompok telah menguasai materi, dimana pertanyaan pertanyaan yang diberikan berhubungan dengan materi yang telah didiskusikan dalam kegiatan kelompok.

4) Penghargaan kelompok (team recognition)

Pemberian penghargaan (rewards) berdasarkan pada rerata poin yang diperoleh oleh kelompok dari permainan.

\section{Sistem Perhitungan Poin Turnamen}

Skor siswa dibandingkan dengan rerata skor yang lalu mereka sendiri, dan poin diberikan berdasarkan pada seberapa jauh siswa menyamai atau melampaui prestasi yang dilaluinya sendiri. Poin tiap anggota tim ini dijumlah untuk mendapatkan skor tim, dan tim yang mencapai kriteria tertentu dapat diberi sertifikasi atau ganjaran (award) yang lain.

Menurut Slavin [10] penghargaan yang diberikan kepada kelompok adalah dengan kriteria dalam tabel 1.

Tabel 1. Kriteria penghargaan kelompok

\begin{tabular}{cc}
\hline Skor rata-rata tim & Penghargaan \\
\hline 15 & Good team \\
20 & Great team \\
25 & Supergreat team \\
\hline
\end{tabular}

Pada hakekatnya pembelajaran kooperatif tipe TGT menuntut keterlibatan siswa aktif secara mental, intelektual, emosional yang mengakibatkan terbentuknya pengetahuan didalam diri siswa.

\section{Populasi dan Sampel}

Populasi dalam penelitian ini adalah seluruh kelas X MAN 2 Model Medan, yang terdiri dari 11 kelas regular dan setiap kelas rata-rata terdiri dari 36siswa. Sampel penelitian yang digunakan sebanyak 2 kelas yang dipilih secara acak sederhana (simple Random Sampling). Kelas eksperimen I diajar dengan strategi Two Stay Two Stray (TSTS) dengan menggunakan power point. Kelas eksperimen II diajar dengan strategiTeams Games Tournament (TGT) dengan menggunakan power point. 


\section{Hasil dan Pembahasan}

Untuk mengetahui hasil belajar siswa diperoleh dari nilai pre-test dan post-test lalu dihitung peningkatan belajar berupa data gain. Data hasil penelitian tersebut disajikan dalam analisis data instrument penelitian, deskripsi hasil penelitian, uji prasyarat perlakuan penelitian, uji prasyarat analisis data, dan uji hipotesis dengan menggunakan SPSS-17 for windows

\section{Hasil Penelitian}

Pada kelas eksperimen 1 diberikan pengajaran dengan menggunakan strategi pembelajaran Two Stay Two Stray (TSTS) dengan didukung media Power Point sedangkan pada kelas eksperimen 2 diberikan pengajaran dengan kooperatif tipe Teams Games Tournament (TGT) dengan didukung media Power Point. Kedua kelas eksperimen, sebelum diberikan perlakuan yang berbeda, terlebih dahulu diberikan tes awal yang bertujuan untuk menguji kemampuan awal masing-masing siswa dan dilakukan tes akhir untuk mengetahui hasil peningkatan belajar siswa.

Untuk data tes awal hasil belajar siswa kelas eksperimen 1 dan kelas eksperimen 2 diperoleh rata-rata, standar deviasi, nilai minimum dan maksimum seperti table 2 dibawah ini:

Tabel 2. Rata-rata, Standar Deviasi, Minimum, Maksimum Data Tes Awal Hasil Belajar kelompok Sampel

\begin{tabular}{cccccc}
\hline Kelas & $\mathrm{N}$ & Mean & Std. Deviation & Minimum & Maksimum \\
\hline eksperimen1 & 30 & 25,6057 & 12,31684 & 0,00 & 50,00 \\
eksperimen2 & 30 & 29,0910 & 11,67094 & 13,64 & 63,64 \\
\hline
\end{tabular}

Berdasarkan tabel 2 diatas, diperoleh rata-rata nilai tes awal kelas eksperimen 1 dengan jumlah siswa 30 sebesar 25,6057 dan nilai tertinggi 50 dan nilai terendah 0, serta standar deviasi sebesar 12,31684 sedangkan untuk data tes awal kelas eksperimen 2dengan jumlah siswa 30 diperoleh rata-rata nilai tes awal sebesar 29,0910 dan nilai tertinggi 63,64 dan nilai terendah 13,64, serta standar deviasi sebesar 11,67094.

Untuk data tes akhir hasil belajar siswa kelas eksperimen 1 dan kelas eksperimen 2 diperoleh rata-rata, standar deviasi, nilai minimum dan maksimum seperti tabel 3 dibawah ini:

Tabel 3. Rata-rata, Standar Deviasi, Minimum, Maksimum Data Tes Akhir Hasil Belajar Kelompok Sampel

\begin{tabular}{cccccc}
\hline Kelas & $\mathrm{N}$ & Mean & Std. Deviation & Minimum & Maximum \\
\hline Eksperimen1 & 30 & 46,9703 & 13,04144 & 22,73 & 81,82 \\
Eksperimen2 & 30 & 51,0607 & 16,30984 & 22,73 & 86,36 \\
\hline
\end{tabular}

Berdasarkan tabel 3 diatasdiperoleh rata-rata nilai tes akhir kelas eksperimen 1 dengan jumlah siswa 30 sebesar 46,9703 dan nilai tertinggi 81,82 dan nilai terendah 22,73, serta standar deviasi sebesar 13,04144 sedangkan untuk data tes akhir kelas eksperimen 2dengan jumlah siswa 30 diperoleh rata-rata nilai tes akhir sebesar 51,0607 dan nilai tertinggi 86,36 dan nilai terendah 22,73, serta standar deviasi sebesar 16,30984.

Untuk data gain hasil belajar siswa kelas eksperimen 1 dan kelas eksperimen 2 diperoleh rata-rata, standar deviasi, nilai minimum dan maksimum seperti tabel 4 dibawah ini:

Tabel 4. Rata-rata, Standar Deviasi, Minimum, Maksimum Data Gain Hasil Belajar Kelompok Sampel

\begin{tabular}{cccccc}
\hline Kelas & $\mathrm{N}$ & Mean & Std. Deviation & Minimum & Maximum \\
\hline Eksperimen1 & 30 & 0,2830 & 0,15672 & 0,00 & 0,67 \\
\cline { 1 - 3 } Eksperimen2 & 30 & 0,3143 & 0,18328 & 0,00 & 0,82 \\
\hline
\end{tabular}

Berdasarkan tabel diatasdiperoleh rata-rata nilai gain kelas eksperimen 1 dengan jumlah siswa 30 sebesar 0,2830 dan nilai tertinggi 0,67 dan nilai terendah 0,00 , serta standar deviasi sebesar 0,15672 sedangkan untuk data 
gain kelas eksperimen 2dengan jumlah siswa 30 diperoleh rata-rata nilai gain sebesar 0,3143 dan nilai tertinggi 0,82 dan nilai terendah 0,00 , serta standar deviasi sebesar 0,18328 .

\section{Uji Hipotesis}

Pengujian Hipotesis menggunakan uji Independent Sampel T-test dengan taraf signifikan $\alpha=0,05$ dan tingkat kepercayaan 95\% pada program SPSS-17 for Windows. Hasil uji hipotesis adalah sebagai berikut;

Tabel 5. Hasil Uji Hipotesis Gain Hasil Belajar SiswaIndependent Samples Test

\begin{tabular}{|c|c|c|c|c|c|c|c|c|c|c|}
\hline & & \multirow[b]{2}{*}{$\mathrm{F}$} & \multirow[b]{2}{*}{ Sig. } & \multirow[b]{2}{*}{$\mathrm{t}$} & \multirow[b]{2}{*}{$\mathrm{df}$} & \multirow{2}{*}{$\begin{array}{l}\text { Sig. (2- } \\
\text { tailed) }\end{array}$} & \multirow{2}{*}{$\begin{array}{c}\text { Mean } \\
\text { Differe } \\
\text { nce }\end{array}$} & \multirow{2}{*}{$\begin{array}{l}\text { Std. } \\
\text { Error } \\
\text { Differe } \\
\text { nce }\end{array}$} & \multicolumn{2}{|c|}{$\begin{array}{l}\text { 95\% Confidence } \\
\text { Interval of the } \\
\text { Difference }\end{array}$} \\
\hline & & & & & & & & & Lower & Upper \\
\hline \multirow[t]{2}{*}{ Gain } & $\begin{array}{l}\text { Equal } \\
\text { variances } \\
\text { assumed }\end{array}$ & .779 & .381 & -.712 & 58 & .480 & -.03133 & .04403 & -.11946 & .05680 \\
\hline & $\begin{array}{l}\text { Equal } \\
\text { variances } \\
\text { not } \\
\text { assumed }\end{array}$ & & & -.712 & 56.634 & .480 & -.03133 & .04403 & -.11951 & .05684 \\
\hline
\end{tabular}

Tabel 5 di atas menunjukan sig (2-tailed) 0,480>0,05. Hal ini mengartikan bahwa hipotesis kedua hasil belajar (Ha) ditolak, ini berarti tidak terdapat perbedaan yang signifikan hasil belajar siswa yang diajarkan dengan strategi pembelajaran TSTS dibandingkan dengan yang diajar dengan kooperatif tipe (TGT) dengan media Power Point pada tingkat kepercayaan $95 \%$.

\section{Peningkatan Hasil Belajar}

Peningkatan hasil belajar siswa dihitung dengan menggunakan rata-rata gain kelas eksperimen 1 dan eksperimen 2. Berdasarkan perhitungan maka diperoleh :

a. Peningkatan hasil belajar kelas Two stay two stray (TSTS) dengan didukung dengan media Power Point (eksperimen 1) sebesar 28,30\%

b. Peningkatan hasil belajar kelas kooperatif tipe Teams Games Tournament (TGT) dengan didukung media Power Point (eksperimen 2) sebesar 31,43\%

\section{Pembahasan}

Hasil uji hipotesis, menghasilkan Ha ditolak, berarti tidak terdapat perbedaan yang signifikan hasil belajar siswa yang diajarkan dengan strategi pembelajaran Two stay two stray (TSTS) dengan media Power Point dibandingkan dengan yang diajar dengan kooperatif tipe Teams Games Tournament (TGT) dengan media Power Point, Hal ini disebabkan oleh :

a. Kurangnya waktu. Salah satu kelemahan dalam strategi pembelajaran yang diterapkan, yaitu membutuhkan waktu yang cukup banyak untuk mendapat hasil yang maksimal. Untuk kemampuan akademis siswa menengah kebawah, untuk mencapai semua indikator yang hendak dicapai waktu 2 x 45 menit tidak cukup. Selain itu, pergantian waktu istirahat dengan masuk mata pelajaran menyebabkan waktu belajar banyak terbuang karena siswa banyak yang telat masuk kedalam kelas. Belum lagi siswa harus mengatur meja sedemikian rupa untuk membentuk kelompok masing - masing sehingga menghabiskan waktu yang tidak sedikit. Seyogyanya waktu belajar yang digunakan tidak lagi terpakai untuk membentuk kelompok dan sudah terbentuk sebelum guru masuk.

b. Masih adanya sikap kerja sama yang tidak baik yang terjadi pada saat test berlangsung. Siswa saling berbagi jawaban ketika guru pengawas lengah.

c.. Kedua strategi pembelajaran yang diterapkan oleh peneliti merupakan jenis strategi yang mengutamakan adanya kerjasama antar siswa dalam kelompok untuk mencapai tujuan pembelajaran. Dalam hal ini sebagian besar aktifitas pembelajaran berpusat pada siswa, yakni mempelajari materi pelajaran serta berdiskusi untuk memecahkan masalah. Sehingga hasil belajar yang diperoleh tidak berbeda secara signifikan. 
Hal ini juga didukung oleh penelitian asriani [11], bahwa hasil belajar siswa yang diajar dengan strategi pembelajaran kooperatif tipe TGT (Teams Games Tournament)yang diintegrasikan dengan media Power Pointtidak memiliki perbedaan yang signifikan dengan siswa yang diajar dengan strategi pembelajaran kooperatif tipe NHT (Numbered Head Together) yang diintegrasikan dengan media Power Point, dikarenakan banyak waktu yang diperlukan dalam penerapan strategi ini, juga suasana yang kurang kondusif pada saat pelaksanaan strategi ini.

\section{Kesimpulan}

Berdasarkan hasil penelitian bahwa Tidak terdapat perbedaan yang signifikan hasil belajar siswa yang diajarkan dengan strategi pembelajaran Two stay two stray (TSTS) dengan media Power Point dibandingkan dengan yang diajar dengan kooperatif tipe Teams Games Tournament (TGT) dengan media Power Point. Hal itu menunjukkan perlu adanya waktu yang lebih banyak untuk melakukan penelitian dengan meggunakan metode TSTS dan TGT juga perlu kordinasi antara guru kelas dan peneliti jgua observers untuk membantu mengawasi dan mengarahkan siswa dalam proses pembelajaran

\section{Referensi}

[1] Sudrajat, A., (2010), Pendidikan Karakter Di Sekolah: http://akhmadsudrajat .wordpress.com (diakses pada juli 2012)

[2] Triana, I.K., (2009), Meningkatkan Disiplin dan Tanggung Jawab Siswa Melalui Sanksi Berjenjang Pada Siswa Kelas III SD No I Sanur T.P. 2009/2010, Laporan Hasil Peneltian Tindakan Kelas Karya Tulis Online, Denpasar.

[3] Hasibuan, F, N., (2012), Pengembangan Model Pembelajaran Untuk Meningkatkan Kreativitas Dan Hasil Belajar Siswa Pada Pokok Bahasan Hidrokarbon Di Man 1 Medan,Skripsi, FMIPA, Universitas Negeri Medan, Medan.

[4] Rizki, Santi Amalia, (2010), Penerapan pembelajaran kooperatif two stay two stray (TSTS) untuk meningkatkan motivasi dan prestasi belajar biologi siswa kelas XI IPA 1 MAN Malang 2 Kota Batu.

[5] Utari, Titin, (2008), Perbedaan Prestasi Belajar Siswa Yang Menggunakan Metode Pembelajaran Kooperatif Tipe TGT (Teams Games Tournament) dengan Metode Pembelajaran Kooperatif Tipe Jigsaw, Skripsi, FMIPA, Unimed.

[6] Marpaung, Naryati. (2010), Pengaruh Pembelajaran Kooperatif Tipe TGT (Team Games Tournament) Terhadap Hasil Belajar Siswa Pada Pokok Bahasan Materi dan Perubahannya di Kelas X SMK Negeri 3 Medan, Skripsi, FMIPA, Unimed, Medan.

[7] Lubis, N.F. (2009), Perbedaan Hasil Belajar Siswa Menggunakan Model Pembelajaran Kooperatif Tipe TGT Dengan Model Pembelajaran Kooperatif Tipe STAD, Skripsi, FMIPA, Unimed, Medan.

[8] Lie, A., (2010), Cooperative Learning: Mempraktekkan Cooperatif Learning di Ruang-Ruang kelas, P.T Grasindo, Jakarta.

[9] Trianto, (2009), Mendesain Model Pembelajaran Inovativ Progresif: Konsep, Landasan, dan Implementasinya Pada Kurikulum Tingkat Satuan Pendidikan (KTSP), Kencana, Jakarta.

[10] Slavin., (2010), Cooperatif Learning Teori, Riset dan Praktek, Nusamedia, Bandung.

[11] Asriani, (2013), Penerapan Strategi Pembelajaran Kooperatif Tipe TGT Dibandingkan Tipe NHT Yang Diintegrasikan Dengan Media Power Point Sebagai Upaya Untuk Meningkatkan Tanggung Jawab Dan Hasil Belajar Kimia Siswa Pada Pokok Bahasan Struktur Atom. Skripsi, FMIPA, Universitas Negeri Medan, Medan. 